\title{
Şeftali yaprağı ekstraksiyonu ile renklendirilen ahşap malzemenin UV yaşlandırma sonrası renk değişim değerlerinin belirlenmesi
}

\section{Determination of color change values after UV exposure of wood material colored with peach leaf extraction}

\author{
Mehmet YENIOCAK, Osman GÖKTAŞ, Ertan ÖZEN, Mehmet ÇOLAK \\ Muğla Sıtkı Koçman Üniversitesi, Teknoloji Fakültesi, Ağaçişleri Endüstri Mühendisliği Bölümü, Muğla, Türkiye
}

\section{Eser Bilgisi / Article Info}

Araştırma makalesi / Research article DOI: $10.17474 /$ artvinofd.385832

Sorumlu yazar / Corresponding author Mehmet YENIOCAK

e-mail: myeniocak@mu.edu.tr ORCID: 0000-0002-8757-5688

Geliş tarihi / Received

29.01.2018

Düzeltme tarihi / Received in revised form

23.05.2018

Elektronik erişim / Online available

29.08.2018

\section{Anahtar kelimeler:}

Şeftali yaprağı

Ekolojik boyalar

Renk değişimi

UV yaşlandırma

Keywords:

Peach Leaf

Ecological dyes

Color change

UV weathering

\begin{abstract}
Özet
Bu çalışmanın amacı; ahşap yüzeyler için sentetik boyalara alternatif yenilenebilir ve sağlığa zararsız tamamen doğal kaynaklardan üretilen ekolojik renklendiricilerin geliştirilmesidir. Çalışmada doğal boyar madde kaynağı olarak şeftali yaprağı, bağlayıcı (mordan) olarak demir sülfat $\left(\mathrm{Fe}_{2}\left(\mathrm{SO}_{4}\right)_{3} .7 \mathrm{H}_{2} \mathrm{O}\right)$, alüminyum sülfat $\left(\mathrm{KAl}_{2}\left(\mathrm{SO}_{4}\right)_{3} \cdot 18 \mathrm{H}_{2} \mathrm{O}\right)$, bakır sülfat $\left(\mathrm{CuSO}_{2} \cdot 5 \mathrm{H}_{2} \mathrm{O}\right)$, ve üzüm sirkesi $\left(\mathrm{CH}_{3} \mathrm{COOH}\right)$ kullanılmıştır. Ağaç malzeme olarak sarıçam (Pinus sylvestris L.) doğu kayını (Fagus orientalis Lipsky), sapsız meşe (Quercus petraea spp) ve ceviz (Juglons regia L.) odunlarından elde edilen deney örnekleri kullanılmıştır. Boyar madde ekstraksiyonu ve elde edilen ekstraksiyonların ağaç malzemeye uygulanmasında ultrasonik destekli daldırma ve klasik daldırma metotları kullanılmıştır. Boyama sonrası elde edilen renkler sıcak ve pastel renkler olarak izlenmiştir. Daha sonra boyanan örnekler 50, 100 ve 150 saatlik sürelerde hızlı yaşlandırma testlerinde tabi tutulmuşlardır. Test sonuçları; şeftali yaprağı ekstraktı ve bağlayıı katkılı çözeltileri ile renklendirilen ahşap malzemelerin belli oranlarda renk değişimlerine uğradıklarını, fakat bu değişim sonucunda ahşap örneklerin daha estetik ve pastel bir görünüme sahip oldukları gözlenmiştir. Bu renklendiriciler, renk değişiminin ihmal edilebileceği alanlarda veya renk değişikliğinden sonra ortaya çıkan renkler dikkate alınarak istenilen yerlerde sentetiklere alternatif çevreci bir malzeme olarak kullanılabilirler.
\end{abstract}

\begin{abstract}
The aim of this study is to improve production of ecologic colorants from natural sources, which renewable and harmless, for surface applications of wooden materials. Peach leaf was used as a source of natural colorant and ferrous sulphate, aluminium sulphate, copper sulphate, and vinegar were chosen as mordant agents. Wood samples procured from Pinus sylvestris L., Fagus orientalis Lipsky, Quercus petraea spp, and Juglons regia L. The ultrasonic-assisted dipping method and traditional dipping method were used for extraction and application of colorants. The warm and pastel colours were observed on wood surfaces after coloration. Additionally, wood samples were exposed to UV weathering test for different periods $(50,100$, and 150 hours). Test results showed that; wood materials coloured with peach leaf extract and mordant additive solutions were found to undergo colour changes at certain ratios. However, as a result of this change, wood samples were observed to have more aesthetic and pastel appearance. These colorants can be used as an alternative environmentalist material to synthetics in the areas where colour change is negligible or where the colours appear after colour change.
\end{abstract}

\section{GiRiş}

Ağaç malzeme çok eski zamanlardan itibaren insanlığa birçok amaçla hizmet etmektedir. İşlenebilme kolaylığı, doğal ve yenilenebilir bir kaynak oluşu, sıcak ve estetik bir görünüme sahip olması gibi özellikleri yapı ve dekorasyonda kullanımında avantaj sağlamaktadır. Fakat bu avantajlarının yanı sıra doğal oluşundan kaynaklı, kullanım yerinde ahşap malzeme fiziksel, kimyasal ve biyolojik unsurlar tarafından tahrip edilebilmektedir. Sektörde ağaç malzemeyi bu unsurlara karşı koruyucu çeşitli kimyasal emprenye maddeleri ve yüzeysel koruma sağlayan üst yüzey işlem maddeleri kullanılmaktadır. Kullanılan bu sentetik maddeler ağaç malzemenin kullanım ömrünü arttırırken, diğer taraftan insan ve çevre sağı̆ğına karşı zararlı uçucu organik bileşikler barındırmaktadır. Sentetik boyar maddelerin iç mekânlarda insanlar üzerinde alerjik sonuçlar doğurması, doğal ürünlerden elde edilen boyar maddeler üzerindeki ilgiyi giderek artırmaktadır (Luciana et al. 1997). Son yıllarda gündeme gelen doğal koruyucu maddeler arasında çevreye zararlı etkileri bulunmayan tanen gibi 
bitkisel ekstraktlar önemli bir yer tutmaktadır (Şen 2001). Ekstraktif bileşenler arasında önemli bir yere sahip olan fenolik bileşenler odunun dayanıklılığını olumlu yönde etkileyerek yapı maddesi olarak kullanılabilme özelliğini arttırmaktadır (Hafızoğlu, 1984).

Literatürde son zamanlarda ahşap malzemelerin ekolojik bitki boyaları ile renklendirilebileceğine ilişkin çalışmalar vardır. Bu kapsamda Göktaş vd. defne yaprakları (2008a), ceviz kabuğu (2008b) gibi bitkilerden elde ettikleri doğal boyaları ağaç malzemelere uygulayarak UV renk değişimi testleri uygulamışlardır. Testler sonucunda doğal boyaların en az sentetikler kadar renk stabilitesi sağladıkları kaydedilmiştir. Peker vd. (2012) meşe palamudundan estetik boya elde ettiklerini ve renk dayanımının istenilen sınırlarda ölçüldüğünü bildirmişlerdir. Yeniocak vd. (2015), çeşitli ahşap türlerini kırmızı pancar boyası ile renklendirerek, renk dayanımlarını incelemişlerdir. Renk stabilizesi dışında Özen vd. (2014) kök boya (Rubia tinctorium) ekstraksiyonları ile ağaç malzemeyi renklendirerek mantarlara ve mikrobik oluşumlara direnç özelliklerini araştırmışlardır. Bu çalışmaların hepsinde doğal boyaların ne denli estetik ve sıcak renkler oluşturduğu ve sentetiklere alternatif olabilecekleri vurgulanmıştır.

Bu çalışmada; ülkemizde şeftali ağacı yapraklarından elde edilen renklendiriciler ile çevre ve insan sağlığına zararsız, doğal ve su-bazlı ahşap koruyucu ve renklendiricilerin elde edilmesi ve geliştirilmesi hedeflenmiştir.

\section{MATERYAL ve YÖNTEM}

\section{Ahşap Deney Örneklerinin Hazırlanması}

Çalışmada kullanılacak olan; sarıçam (Pinus sylvestris L.), Doğu kayını (Fagus orientalis Lipsky), sapsız meşe (Quercus petraea spp) ve ceviz (Juglans regia L.) İzmir bölgesinde bu işin ticaretini yapan bir işletmeden temin edilerek Muğla Sıtkı Koçman Üniversitesi Teknoloji Fakültesi'ne getirilmiştir. Ağaç malzeme TS 4176'ya göre markalanmış ve hızlı yaşlandırma testleri için; 150x75×5 $\mathrm{mm}$ ölçülerinde kesilmişlerdir. Kesilen parçalar ortamın sıcaklığına $\left( \pm 220^{\circ} \mathrm{C}\right)$ uygun olarak, $( \pm \% 12$ rutubet ve \pm $\% 65$ bağıl nem) hava kurusu hale gelinceye kadar bekletilmiştir.

\section{Boyar MaddeEkstraksiyonu}

Şeftali yaprakları Hatay yöresinden toplanarak gölgede kurutulmuş ve ince ince kıyıldıktan sonra parçalanan bitkiler \%5 konsantrasyonda olacak şekilde saf su içerisine alındıktan sonra ultrasonik banyo kazanında $45{ }^{\circ} \mathrm{C}$ sıcaklıkta, $180 \mathrm{~W}$ Ultrason çıkış gücünde, $180 \mathrm{dk}$ boyunca ekstraksiyona tabi tutulmuştur. Süre sonunda yaprak süspansiyonu süzgeç kâğıdı ile süzülerek katı kısımlar ayrılmış ve boyar madde elde edilmiştir.

\section{Mordan Karışımları}

Mordan maddesi olarak kullanılan demir sülfat $\left(\mathrm{Fe}_{2}\left(\mathrm{SO}_{4}\right)_{3} 7 \mathrm{H}_{2} \mathrm{O}\right)$, alüminyum sülfat $\left(\mathrm{Al}_{2}\left(\mathrm{SO}_{4}\right)_{3} 18 \mathrm{H}_{2} \mathrm{O}\right)$, ve bakır sülfat $\left(\mathrm{CuSO}_{2} 5 \mathrm{H}_{2} \mathrm{O}\right)$ Kimetsan Ltd şirketinden, üzüm sirkesi $\left(\mathrm{CH}_{3} \mathrm{COOH}\right)$ Fersan firmasından temin edilmiştir. Mordan maddeleri boyar madde içerisine katılarak farklı renk konsantrasyonları elde edilebildiği gibi boyanın, ahşap malzemeye daha iyi bağlanmasına yardımcı olmaktadır. Ekstraksiyon işleminden sonra elde edilen boyalar Çizelge $1^{\prime}$ de belirtildiği oranlarda mordan maddeleri ile karıştırılarak mordanlı konsatrasyonlar elde edilmiştir.

Çizelge 1 Boya çözeltisi+mordan karışım oranları

\begin{tabular}{lll}
\hline Boyar madde & Mordan & Karışım (\%) \\
\hline \multirow{3}{*}{ Şeftali yaprağı } & Kontrol & 0 \\
& Demir sülfat & 3 \\
& Alüminyum şapı & 5 \\
& Sirke & 10 \\
\hline
\end{tabular}

\section{Ahşap Örneklerin Boyanması}

Ahşap örnekler ultrasonik destekli daldırma ve klasik daldırma metotlarıla boyanmıştır. Boyar maddelerin ahşap örneklere uygulanma şartları Çizelge 2'de verilmiştir. Ultrasonik yöntem; bitkilerden boyar madde elde etmede ve bu boyaların, gıda, yün, pamuk ve deri malzemelerine uygulanmada denenmiştir. Yöntemin, boya ektraksiyonu ve malzemelere uygulanmasında kolaylıklar ve avantajları olduğu, yapılan bazı çalışmalarla ortaya konulmuştur. Bu avantajlar; düşük sıcaklıklarda boyama işlemi gerçekleştirildiğinden enerji tasarrufu sağlamakta ve işlem süresini kısaltmakta, yardımcı kimyasal madde tüketimi azalmakta dolayısıyla atık yükünde azalma meydana gelmekte, renk tonunda kontrol imkanı sağlamakta, düşük işlem maliyetine ve 
dolayısıyla artan rekabet gücüne neden olmakta, (Kamel et al. 2005; Kamel 2007; Perincek vd. 2009; Sivakumar et al. 2009) ve boyar maddenin uygulanan malzeme derinliklerine daha fazla nüfuz ettiği (Tavman 2009) şeklinde belirtilmiştir. Ağaç malzemenin poroz yapısı dikkate alındığında, bu yöntemin kullanılması ile liflerin arasına boyar maddelerin nüfuzunun kolaylaşacağı beklenebilir.

Çizelge 2. Boyar çözeltinin ahşap örneklere uygulanma şartları

\begin{tabular}{llll}
\hline Boyar madde & $\begin{array}{l}\text { Ultrason çıkış } \\
\text { gücü }(\mathbf{W})\end{array}$ & Sıcaklık $\left({ }^{\circ} \mathrm{C}\right)$ & Süre (dk) \\
\hline \multirow{3}{*}{ Şeftali yaprağı̆ } & $\begin{array}{l}\text { Kontrol (klasik } \\
\text { daldırma) } \\
\end{array}$ & 45 & 60 \\
& 300 & & \\
\hline
\end{tabular}

\section{Hızlı Yaşlandırma Testleri}

Hızlı yaşlandırma deneyleri için "Accelerated Weathering Tester (QUV/SPRAY)" cihazı kullanımıştır. Hızlandırımış yaşlandırma cihazının çalışma şartları iki periyottan meydana gelmektedir. Birincisi kondenzasyon aşamasıdır. Bu aşama; dış ortam şartlarının taklidini yapabilmesi için belirli sürelerde ortamın sıcaklığını, soğukluğunu ve rutubet miktarını değiştirerek örnek parçalara sıcak buhar püskürtülerek ve örneklerin genleşmesi sağlanmaktadır. íkinci aşama UV aşamasıdır. Hızlı yaşlandırma süreci; kondenzasyon periyodunda 4 saat, UV periyodunda ise 8 saat olacak şekilde uygulanmıştır. Deney örnekleri, her 50 saatlik yaşlandırmadan sonra cihazdan alınarak, renk ölçümleri yapılmış ve tekrar cihaza yerleştirilmiştir. Bu işlem, her örnek için, 50, 100 ve 150 saatler de tekrar edilmiştir.

\section{Renk Ölçümü}

Ekstraktların ahşap örnekler üzerindeki renk durumlarının belirlenmesi için, portatif bir renk okuyucu (Konica Minolta-Color Reader (R-10) cihazı kullanılmıştır. Renk ölçümlerinde, 150x75×5 mm ölçülerindeki boyanmış ahşap örneklerin, yüzeyinde, ahşap renginin homojen olmaması nedeniyle, tüm ölçümler, önceden belirlenmiş çaprazlama dört noktadan yapılmış ve ortalamaları kullanılmıştır. Renklerin sınıflandırılmasında standardı (ISO 2470 (CIELAB-76; Commission International de I'Eclaireage) esas alınmıştır. Hızlandırıımış yaşlandırmadan dolayı meydana gelen renk değişiklikleri aşağıdaki formüllerle hesaplanmıştır.

$$
\begin{aligned}
& \Delta \mathrm{L}^{*}=\mathrm{L} * \mathrm{f}-\mathrm{L} * \mathrm{i} \\
& \Delta \mathrm{a} *=\mathrm{a} * \mathrm{f}-\mathrm{a} *_{\mathrm{i}} \\
& \Delta \mathrm{b} *=\mathrm{b} * \mathrm{f}-\mathrm{b}{ }^{*} \mathrm{i} \\
& \Delta \mathrm{E} *=\sqrt{\Delta L^{* 2}+\Delta a^{* 2}+\Delta b^{* 2}}
\end{aligned}
$$

Burada;

$\Delta \mathrm{L}^{*}, \Delta \mathrm{a}^{*}$ ve $\Delta \mathrm{b}^{*}$, değerleri renklerin ilk hali (i) ile son hali (f) arasında oluşan değişiklikler, $\Delta E^{*}$, renklerin $L$, $a$, ve $b$ yönlerinde meydana gelen toplam renk değişikliklerini göstermektedir. Burada en yüksek değer en yüksek renk değişimini göstermektedir.

\section{BULGULAR}

\section{Renk Değișim Verileri}

Boyar maddeler yüzeye uygulandıkları zaman transparan bir örtücülük sağlamakta ayrıca elde edilen renkler pastel ve sıcak tonlar şeklindedir. Boyar maddelerin, deney örklerine uygulandıktan sonra hızlı yaşlandırma testinde elde edilen renk değişim değerleri Çizelge 3 ve 4 'te grafiksel gösterimleri ise Şekil 1'de verilmiştir.

Sonuçlara göre; sarıçam grubunda en düşük renk değişim değeri şeftali yaprağı + sirke karışımı ve kontrol grubunun ultrasonik destekli daldırma yöntemi ile uygulamasında sırasıyla $\Delta \mathrm{E} 29.14$ ve 30.02 ölçülürken klasik daldırma uygulamasında yöntem ile uygulamada kontrol grubunda $\Delta \mathrm{E} 23.40$ olarak ölçülmüştür. Bakır sülfat ve alüminyum sülfat mordanı kullanılan gruplarda her iki uygulamada da yakın renk değişim değerleri ölçüldüğü görülmüştür. 
Çizelge 3. Hızlı yaşlandırma testi renk değişim bulguları

\begin{tabular}{|c|c|c|c|c|c|c|c|c|c|c|c|c|c|c|c|c|c|c|}
\hline \multirow[t]{7}{*}{ Odun türü } & \multirow{2}{*}{$\begin{array}{l}\text { Boyama } \\
\text { metodu }\end{array}$} & \multirow[t]{2}{*}{ Boya çözeltisi } & \multicolumn{5}{|c|}{ Boyama sonrası } & \multicolumn{4}{|c|}{50 saat UV sonrası } & \multicolumn{4}{|c|}{100 saat UV sonrası } & \multicolumn{3}{|c|}{150 saat UV sonrası } \\
\hline & & & $\Delta L^{*}$ & $\Delta a^{*}$ & $\Delta b^{*}$ & $\Delta E^{*}$ & $\Delta L^{*}$ & $\Delta a^{*}$ & $\Delta b^{*}$ & $\Delta E^{*}$ & $\Delta L^{*}$ & $\Delta a^{*}$ & $\Delta b^{*}$ & $\Delta E^{*}$ & $\Delta L^{*}$ & $\Delta a^{*}$ & $\Delta b^{*}$ & $\Delta E^{*}$ \\
\hline & \multirow{5}{*}{ 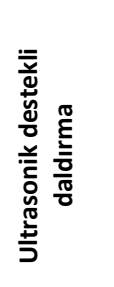 } & Kontrol (mordansız) & -7.88 & 0.17 & 10.82 & 13.38 & -16.67 & 9.83 & 15.92 & 25.05 & -20.20 & 11.94 & 15.93 & 28.36 & -23.23 & 12.02 & 14.75 & 30.02 \\
\hline & & Şeftali + Demir & -41.11 & -8.16 & -8.36 & 42.74 & -48.61 & -5.09 & -10.43 & 49.98 & -49.99 & -5.03 & -11.57 & 51.56 & -52.27 & -5.03 & -12.37 & 53.95 \\
\hline & & Şeftali + Alüm & -10.03 & 0.37 & 17.54 & 20.20 & -19.71 & 12.72 & 15.65 & 28.20 & -22.83 & 13.86 & 13.84 & 30.08 & -25.48 & 14.54 & 12.93 & 32.06 \\
\hline & & Şeftali + Bakır & -10.07 & -1.08 & 12.22 & 15.86 & -22.76 & 9.35 & 13.31 & 27.97 & -26.53 & 11.21 & 12.56 & 31.41 & -28.73 & 11.56 & 11.65 & 33.09 \\
\hline & & Şeftali + Sirke & -7.78 & 1.05 & 9.31 & 12.17 & -14.77 & 8.92 & 15.47 & 23.17 & -19.27 & 12.63 & 15.97 & 28.03 & -20.86 & 13.13 & 15.56 & 29.14 \\
\hline \multirow{10}{*}{ 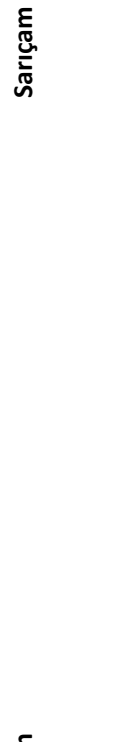 } & \multirow{5}{*}{ 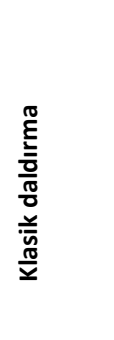 } & Kontrol (mordansız) & -2.15 & -4.65 & 8.05 & 9.54 & -11.48 & 4.00 & 17.81 & 21.56 & -15.55 & 6.03 & 17.33 & 24.05 & -17.27 & 5.64 & 14.75 & 23.40 \\
\hline & & Şeftali + Demir & -31.76 & -8.88 & -6.80 & 33.67 & -42.65 & -5.39 & -8.18 & 43.76 & -45.55 & -5.05 & -10.32 & 46.97 & -47.81 & -4.73 & -11.07 & 49.30 \\
\hline & & Şeftali + Alüm & -9.35 & 4.69 & 9.36 & 14.04 & -19.17 & 13.13 & 13.27 & 26.76 & -21.93 & 14.61 & 11.81 & 28.87 & -24.29 & 13.88 & 11.62 & 30.29 \\
\hline & & Şeftali + Bakır & -10.63 & -2.57 & 14.23 & 17.94 & -20.84 & 7.20 & 15.46 & 26.93 & -24.89 & 8.58 & 14.56 & 30.09 & -27.94 & 9.65 & 13.45 & 32.47 \\
\hline & & Şeftali + Sirke & -3.31 & 0.77 & 4.64 & 5.74 & -14.02 & 9.97 & 15.21 & 22.96 & -18.18 & 11.95 & 14.96 & 26.40 & -23.94 & 14.01 & 12.80 & 30.54 \\
\hline & \multirow{5}{*}{ 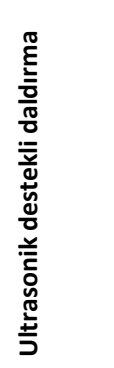 } & Kontrol (mordansız) & -4.46 & -0.63 & 5.76 & 7.31 & -9.27 & 3.24 & 10.03 & 14.03 & -12.34 & 4.92 & 12.07 & 17.95 & -13.41 & 5.95 & 12.59 & 19.33 \\
\hline & & Şeftali + Demir & -27.22 & -12.21 & -9.03 & 31.17 & -34.13 & -10.02 & -9.57 & 36.83 & -36.98 & -8.79 & -10.25 & 39.36 & -37.26 & -8.55 & -10.58 & 39.66 \\
\hline & & Şeftali + Alüm & -4.33 & -1.34 & 12.92 & 13.69 & -12.47 & 6.41 & 11.17 & 17.92 & -15.67 & 8.87 & 12.08 & 21.68 & -16.30 & 8.17 & 10.21 & 20.89 \\
\hline & & Şeftali + Bakır & -7.95 & -4.08 & 9.44 & 12.99 & -15.30 & 1.07 & 10.80 & 18.75 & -18.76 & 2.54 & 10.27 & 21.54 & -20.23 & 3.27 & 9.94 & 22.77 \\
\hline & & Şeftali + Sirke & -3.84 & -0.10 & 4.13 & 5.64 & -9.01 & 3.29 & 9.47 & 13.48 & -11.31 & 5.45 & 12.03 & 17.39 & -11.73 & 5.99 & 11.81 & 17.69 \\
\hline \multirow{5}{*}{ 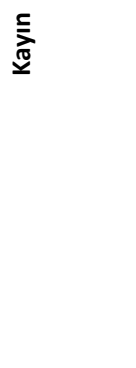 } & \multirow{5}{*}{$\begin{array}{l}\stackrel{\pi}{\xi} \\
\frac{\underline{5}}{0} \\
\frac{\pi}{0} \\
\frac{10}{\bar{n}} \\
\frac{\pi}{x}\end{array}$} & Kontrol (mordansız) & -3.39 & -0.06 & 4.37 & 5.53 & -7.95 & 2.95 & 9.28 & 12.57 & -11.14 & 5.14 & 11.44 & 16.77 & -11.99 & 5.49 & 11.15 & 17.27 \\
\hline & & Şeftali + Demir & -27.69 & -11.55 & -10.07 & 31.64 & -34.75 & -8.86 & -8.67 & 36.89 & -36.09 & -8.46 & -9.04 & 38.15 & -37.17 & -7.20 & -8.99 & 38.91 \\
\hline & & Şeftali + Alüm & -4.37 & -1.16 & 12.03 & 12.85 & -13.44 & 7.37 & 11.01 & 18.87 & -15.82 & 8.28 & 10.35 & 20.63 & -16.44 & 8.00 & 9.20 & 20.47 \\
\hline & & Şeftali + Bakır & -6.08 & -3.53 & 11.12 & 13.16 & -15.90 & 2.72 & 11.57 & 19.84 & -18.55 & 4.26 & 10.73 & 21.85 & -20.11 & 4.42 & 10.26 & 23.00 \\
\hline & & Şeftali + Sirke & -5.05 & 0.15 & 4.94 & 7.07 & -10.49 & 4.05 & 10.13 & 15.13 & -11.50 & 5.51 & 12.08 & 17.56 & -11.63 & 4.86 & 11.79 & 17.25 \\
\hline
\end{tabular}


Çizelge 4. Hızlı yaşlandırma testi renk değişim bulguları

\begin{tabular}{|c|c|c|c|c|c|c|c|c|c|c|c|c|c|c|c|c|c|c|}
\hline \multirow{2}{*}{ Odun türü } & \multirow{2}{*}{ Boyama metodu } & \multirow{2}{*}{ Boya çözeltisi } & \multicolumn{4}{|c|}{ Boyama sonrası } & \multicolumn{4}{|c|}{50 saat UV sonrası } & \multicolumn{4}{|c|}{100 saat UV sonrası } & \multicolumn{4}{|c|}{150 saat UV sonrası } \\
\hline & & & $\Delta L^{*}$ & $\Delta a^{*}$ & $\Delta b^{*}$ & $\Delta E^{*}$ & $\Delta L^{*}$ & $\Delta a^{*}$ & $\Delta b^{*}$ & $\Delta E^{*}$ & $\Delta L^{*}$ & $\Delta a^{*}$ & $\Delta b^{*}$ & $\Delta E^{*}$ & $\Delta L^{*}$ & $\Delta a^{*}$ & $\Delta b^{*}$ & $\Delta E^{*}$ \\
\hline \multirow{10}{*}{$\stackrel{N}{\tilde{d}}$} & \multirow{5}{*}{ 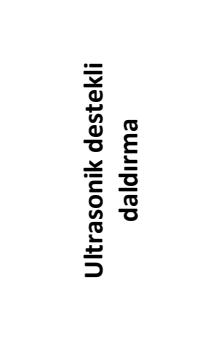 } & Kontrol (mordansız) & -0.46 & -0.05 & 2.63 & 2.67 & -1.81 & 2.80 & 9.49 & 10.05 & -8.04 & 4.46 & 10.77 & 14.16 & -6.49 & 6.47 & 11.07 & 14.36 \\
\hline & & Şeftali + Demir & -23.63 & -8.33 & -11.71 & 27.66 & -25.19 & -6.94 & -9.22 & 27.70 & -25.77 & -6.98 & -9.53 & 28.35 & -25.88 & -6.76 & -9.26 & 28.30 \\
\hline & & Şeftali + Alüm & -2.60 & -2.02 & 7.48 & 8.17 & -6.72 & 3.10 & 8.23 & 11.06 & -10.76 & 6.06 & 9.32 & 15.46 & -13.21 & 6.53 & 8.13 & 16.83 \\
\hline & & Şeftali + Bakır & -4.71 & -1.29 & 4.55 & 6.67 & -10.01 & 2.18 & 6.84 & 12.31 & -13.28 & 2.99 & 5.79 & 14.79 & -15.75 & 3.38 & 3.94 & 16.58 \\
\hline & & Şeftali + Sirke & -1.32 & -0.61 & 4.72 & 4.93 & -4.72 & 2.94 & 8.30 & 9.99 & -6.65 & 4.16 & 8.71 & 11.72 & -6.60 & 5.15 & 9.31 & 12.52 \\
\hline & \multirow{5}{*}{$\begin{array}{l}\frac{\pi}{\xi} \\
\frac{\underline{5}}{\frac{0}{\pi}} \\
\frac{\pi}{0} \\
\frac{.0}{\overline{5}} \\
\frac{\pi}{\underline{\pi}}\end{array}$} & Kontrol (mordansız) & -1.58 & 0.15 & 2.38 & 2.86 & -4.66 & 3.15 & 9.14 & 10.73 & -8.97 & 5.21 & 8.97 & 13.71 & -10.20 & 6.09 & 9.28 & 15.07 \\
\hline & & Şeftali + Demir & -22.00 & -6.33 & -10.65 & 25.25 & -23.51 & -5.59 & -8.08 & 25.47 & -24.34 & -5.54 & -8.02 & 26.21 & -25.22 & -4.99 & -7.91 & 26.90 \\
\hline & & Şeftali + Alüm & -2.69 & -0.97 & 6.83 & 7.40 & -7.38 & 3.57 & 8.64 & 11.91 & -11.29 & 5.96 & 8.32 & 15.24 & -12.92 & 6.06 & 7.73 & 16.23 \\
\hline & & Şeftali + Bakır & -5.05 & -2.10 & 6.16 & 8.24 & -11.16 & 1.99 & 8.72 & 14.30 & -14.95 & 2.72 & 7.65 & 17.01 & -17.26 & 3.47 & 5.87 & 18.56 \\
\hline & & Şeftali + Sirke & -3.57 & 0.16 & 2.47 & 4.34 & -7.03 & 4.52 & 9.92 & 12.97 & -9.55 & 5.60 & 10.49 & 15.25 & -8.48 & 3.93 & 7.22 & 11.81 \\
\hline \multirow{10}{*}{ 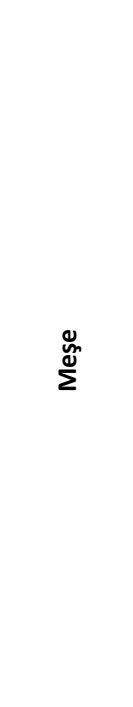 } & \multirow{5}{*}{ 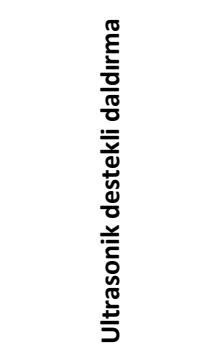 } & Kontrol (mordansız) & -4.50 & -0.69 & 3.70 & 5.87 & -6.77 & 2.52 & 8.94 & 11.50 & -10.90 & 4.10 & 9.21 & 14.84 & -13.07 & 7.43 & 11.80 & 19.11 \\
\hline & & Şeftali + Demir & -37.99 & -9.24 & -19.78 & 43.82 & -38.72 & -7.82 & -18.06 & 43.43 & -38.55 & -7.66 & -17.49 & 43.02 & -38.60 & -7.18 & -16.95 & 42.76 \\
\hline & & Şeftali + Alüm & -4.32 & -2.68 & 11.37 & 12.45 & -10.90 & 4.64 & 11.92 & 16.80 & -16.89 & 7.91 & 11.07 & 21.69 & -19.61 & 8.89 & 9.49 & 23.53 \\
\hline & & Şeftali + Bakır & -15.11 & -0.91 & 4.60 & 15.82 & -18.79 & 1.40 & 5.58 & 19.64 & -21.52 & 2.21 & 6.21 & 22.51 & -24.05 & 3.47 & 4.08 & 24.64 \\
\hline & & Şeftali + Sirke & -2.85 & -0.64 & 2.09 & 3.59 & -6.33 & 2.68 & 9.72 & 11.90 & -10.24 & 6.79 & 12.80 & 17.74 & -11.75 & 7.77 & 12.51 & 18.83 \\
\hline & \multirow{5}{*}{ 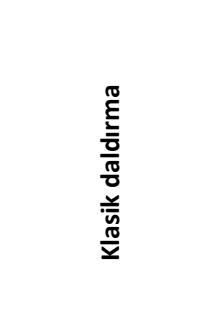 } & Kontrol (mordansız) & -1.60 & -0.53 & 2.20 & 2.77 & -15.88 & 3.57 & 5.27 & 17.11 & -10.97 & 7.26 & 13.58 & 18.90 & -13.83 & 7.70 & 12.03 & 19.87 \\
\hline & & Şeftali + Demir & -29.86 & -8.79 & -13.26 & 33.83 & -35.10 & -7.09 & -12.32 & 37.87 & -36.61 & -6.80 & -12.57 & 39.30 & -37.03 & -6.05 & -12.60 & 39.58 \\
\hline & & Şeftali + Alüm & -3.54 & -2.16 & 7.16 & 8.27 & -8.99 & 4.08 & 10.80 & 14.64 & -12.78 & 5.41 & 10.29 & 17.27 & -15.67 & 8.00 & 10.73 & 20.61 \\
\hline & & Şeftali + Bakır & -14.60 & -0.92 & 1.42 & 14.70 & -18.74 & 0.64 & 3.01 & 18.99 & -20.99 & 1.68 & 3.26 & 21.31 & -23.07 & 2.88 & 3.03 & 23.45 \\
\hline & & Şeftali + Sirke & -2.58 & -0.48 & 2.74 & 3.80 & -6.53 & 2.91 & 10.44 & 12.66 & -11.64 & 7.45 & 8.38 & 16.16 & -14.83 & 6.00 & 9.94 & 18.83 \\
\hline
\end{tabular}



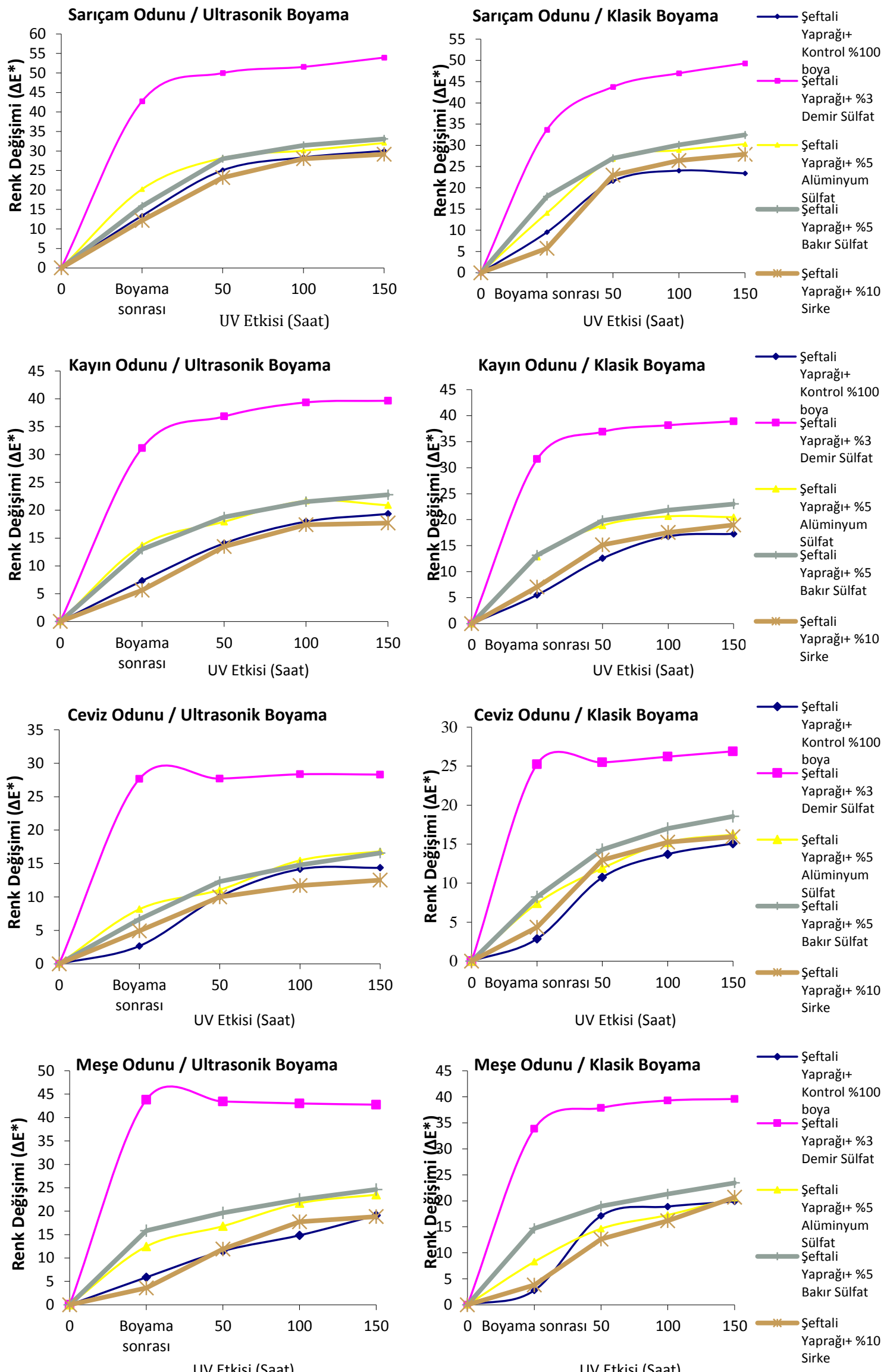

Şekil 1. Renk değişim değerlerinin grafiksel gösterimi 
En yüksek renk değişim değeri ise, her iki yöntemle de uygulamada şeftali yaprağı + demir sülfat karışımı ile renklendirilen örneklerde görülmüştür.

Kayın grubunda en düşük renk değişimi ultrasonik destekli ve klasik daldırma metodunda da kontrol ve sirke mordanının kullanıldı̆̆ı gruplarda ölçülürken, bakır sülfat ve alüminyum mordanı uygulanan örneklerden de yakın sonuçlar elde edildiği ve en yüksek renk değişiminin demir sülfat karışımı uygulanan grupta tespit edildiği görülmüştür.

Ceviz odunu örneklerinin şeftali yaprağı ve mordanlı konsatrasyonlarının ultrasonik destekli boyama yöntemi ile renklendirilmesi sonrası 150 saatlik hızlı yaşlandırma verilerine göre; en düşük renk değişim değerleri $\Delta \mathrm{E}$, sirke mordanı uygulamasında 12.52, kontrol grubunda 14.36, bakır sülfat ve alüminyum örneklerinde ise sırasıyla 16.58 ve 16.83 olarak ölçülmüştür. Bu değerler klasik daldırma yönteminde; sirke mordanında 11.81, kontrol örneklerinde 15.07, alüminyum grubunda 16.23 ve bakır sülfat uygulanan örneklerde 18.56 olarak ölçülmüştür. Her iki yöntem ile uygulamadada en yüksek renk değişim değeri şeftali yaprağı + demir sülfat mordanı ile renklendirilen örneklerde tespit edilmiştir.

Meşe odunu örneklerinin renk değişim bulguları incelendiğinde; en az değişimin diğer odun türlerinde de olduğu gibi kontrol ve sirke mordanı uygulanan gruplarda olduğu, alüminyum ve bakır sülfat mordanları kullanılan gruplarda da yakın değerler tespit edildiği görülmüştür.

\section{TARTIŞMA ve SONUÇ}

Şeftali yaprağından ultrasonik destekli ekstraksiyon metodu ile elde edilen boyar maddeler farklı mordan ilaveleriyle klasik ve ultrasonik destekli boyama metotlarıyla sarıçam, kayın, ceviz ve meşe odunu türlerine uygulanmıştır. Bu örnekler 50, 100 ve 150 saat olmak üzere 3 aşamada hızlı yaşlandırma testlerine maruz bırakılmıştır.

Genel olarak tüm örneklerde yaşlandırma testlerinin ilk 50 saatinde hızı bir renk değişimine uğradığı, daha sonraki periyotlarda değişimin yavaşladığı ve stabil bir çizgide seyrettiği görülmüştür. En yüksek renk değişim değeri tüm odun türlerinde demir sülfat mordanı uygulanan örneklerde tespit edilmiştir. Bilindiği üzere mordanlar boyar maddelere eklenerek, farklı renk tonları elde edilmekte ve boyar maddelerin ahşap malzemeye bağlanmasını güçlendirmek için kullanılmaktadır. Çalışmada en yüksek renk değişim değerlerinin demir sülfat mordanının kullanıldığı örneklerde ölçülmesi şu şekilde açıklanabilir. Demir sülfat, şeftali yaprağından elde edilen boyar madde içerisine karıştırıldığında diğer mordanlardan elde edilen renklere göre daha koyu bir ton elde edilmiştir. Çözeltinin ahşap yüzeylere uygulanması sonrası, yüzeye bağlanan demir partiküllerinin korozyona uğraması ile yüzeydeki renk değişim değerlerinin daha yüksek oranlarda ölçülmesine neden olmaktadır. Ayrıca, genel olarak değerlendirildiğinde boyar maddelerin ahşap örneklere uygulama metodunun renk değişimine etkisinin olmadığı görülmüştür. Bu çalışmada elde edilen renk değişim sonuçları, Yeniocak (2013); Yeniocak vd. (2016), Özen vd. (2014), Göktaş vd. (2008a) ve (2008b) çalışmalarından elde edilen sonuçlarla benzerlik göstermektedir.

Renk kavramı kişiden kişiye farklılık gösteren estetik bir değerdir, bu sebeple her mordan ahşap yüzeylerde farklı bir renk karakterini yansıttığından tercih edilmesi olasıdır. Dahası demir sülfat mordanı uygulanan örneklerin yaşlandırma sonrası, çok daha estetik ve göze hitap eden bir karaktere bürünmesi tercih edilme olasılığını arttırmaktadır.

Sonuç olarak; insan sağlığı ve çevrenin önem kazandığı günümüzde, doğal kaynaklardan elde edilen ekolojik boyar maddelerin kullanımı önem kazandığı günümüzde şeftali yaprağından elde edilen boyalar, sentetiklere alternatif olarak ahşap yüzeylerde kullanılabilirler.

\section{TEŞEKKÜR}

Bu çalışmada kullanılan veriler TÜBITAK tarafından desteklenen "Ultrasonik Yöntem Kullanılarak Bitki Boyaları ile Boyanan Ahşap Malzemenin Yıkanma Performansları (Boya Tutunma) ve UV-Hızlı Yaşlandırma Şartları Altındaki Renk Değişim Değerlerinin Belirlenmesi" isimli ve 1010141 no'lu proje kapsamında elde edilmiştir. TÜBіTAK' a katkı ve desteklerinden dolayı teşekkür ederiz. 


\section{KAYNAKLAR}

Göktaş O (2013) Malzemenin Yıkanma Performansları (Boya Tutunma) ve UV-Hızlı Yaşlandırma Şartları Altındaki Renk Değişim Değerlerinin Belirlenmesi. TÜBiTAK-TOVAG 1100141 nolu Proje.

Göktaş O, Duru EM, Yeniocak M, Ozen E (2008a) Determination of the Color Stability of an Environmentally Friendly Wood Stain Derived from Laurel (Laurus nobilis L.) Leaf Extracts Under UV Exposure. Forest Products Journal, 58 (1/2): 77-80.

Göktaş O, Baysal E, Ozen E, Mammadov R, Duru EM (2008b) Decay Resistance and Color Stability of Wood Treated With Juglans Regia Extract. Wood Research, 53(3): 27-36.

Hafızoğlu H (1984) Orman Yan Ürünleri Kimyasıve Teknolojisi Ders Notları, Karadeniz Teknik Üniversitesi, Orman Fakultesi, Trabzon.

Kamel M, Reda M, El-Shishtawy M, Yussef BM, Mashaly H (2005) Ultrasonic assisted dyeing: III. Dyeing of wool with lac as a natural dye Dyes and Pigments, 65:(2),103-110.

Kamel M, Reda M, El-Shishtawy M, Youssef BM, Mashaly H (2007) Ultrasonic assisted dyeing. IV. Dyeing of cationised cotton with lac natural dye, Dyes and Pigments, 73: 279-284.

Luciana GA, Lusia P, Paola B, Alessandra B (1997) Rubia tinctorium a Source of Natural Dyes: Agronomic Evaluation, Quantitative Analysis of Alizarin and Industrial Assays. Idustrial Crops and Products, 6: 303-311.

Özen E, Yeniocak M, Çolak M, Göktaş O, Koca I (2014) Colorability of wood material with Punica granatum and Morus nigra extracts. BioRes. 9(2): 2797-2807.

Peker H, Atılgan A, Ulusoy H, Göktaş O (2012) Usage Opportunities of the Natural Dye Extracted from Acorn (Quercus ithaburensis
Decaisne) in the Furniture Industry Upper Surface Treatment. International Journal of Physical Sciences, 7(40): 5552-5558.

Perincek S, Kerim D, Ayşegül E, Körlü M, Bahtiyar i (2009) Tekstil Terbiye Iş̧lemleri Sırasında Ultrason Cihazı İle Çalışmada İşlem Verimliliğine Etki Edebilecek Faktörlerin Incelenmesi. Tekstil ve Konfeksiyon (1)70-76.

Şen S (2001) Bitki Fenollerinin Odun Koruyucu Etkilerinin Belirlenmesi, Doktora Tezi, Zonguldak Karaelmas Üniversitesi, Fen Bilimleri Enstitüsü, Zonguldak. 300s.

Sivakumar V, Lakshmi Anna J, Vijayeeswarri J, Swaminathan G (2009) Ultrasound assisted enhancement in natural dye extraction from beetroot for industrial applications and natural dyeing of leather Ultrasonics Sonochemistry 16: 782-789.

Tavman Ş, Kumcuoğlu S, Akaya Z (2009) Bitkisel Ürünlerin Atıklarından Antioksidan Maddelerin Ultrason Destekli Ekstraksiyonu, 34 (3): 175-182.

TS 2470 (1976) Odunda Fiziksel ve Mekanik Deneyler İçin Numune Alma Metotları ve Genel Özellikler.

TS 4176 (1984) Odunda Fiziksel ve Mekaniksel Özelliklerinin Tayini İçin Homojen Meşcerelerden Numune Alma ve Laboratuar Numunesi Alınması. T.S.E., Ankara.

Yeniocak M. (2013) Ultrasonik Yöntem Ile Elde Edilen Çeşitli Doğal Boyar Maddelerle Ahşap Malzemenin Boyanabilirliğinin İncelenmesi. Kahramanmaraş Sütçü İmam Üniversitesi, Fen Bilimleri Enstitüsü, Doktora Tezi, 330s.

Yeniocak M, Göktaş O, Çolak M, Özen E, Uğurlu M (2015) Natural coloration of wood material by red beetroot (Beta vulgaris) and determination color stability under UV exposure. Maderas. Ciencia y tecnología, 17(4): 711-722., Doi: 10.4067/S0718$221 \times 2015005000062$. 